\title{
Establishing Kleingrass and Bermudagrass Pastures using Glyphosate and Tebuthiuron
}

\author{
J.R. BAUR
}

Abstract

Tebuthiuron and glyphosate were applied at 1.1 and $2.2 \mathrm{~kg} / \mathrm{ha}$ in 1976 before land preparation for the sprigging of Coastal Bermudagrass or seeding of kleingrass in the claypan region of Texas. Tebuthiuron at $1.0 \mathrm{~kg} / \mathrm{ha}$ was re-applied in February 1977 either as the $80 \%$ wettable powder spray or as $3.2-\mathrm{mm}$ or $1.6-\mathrm{mm}$ extruded pellets, to a set of plots superimposed across the 1976 plots. Kleingrass top-growth production in 1977 was increased by the preplanting treatment with glyphosate in both rates and tebuthiuron at the low rate. Tebuthiuron at $2.2 \mathrm{~kg} / \mathrm{ha}$ prevented establishment of kleingrass. Bermudagrass cover was significantly increased by a preplanting application of tebuthiuron at 1.1 $\mathrm{kg} / \mathrm{ha}$, but was not affected by preplanting application of glyphosate. Tebuthiuron at $2.2 \mathrm{~kg} / \mathrm{ha}$ had no effect (beneficial or detrimental) on Bermudagrass cover. Crude protein content was higher in kleingrass from plots treated in 1976 with tebuthiuron at $1.1 \mathrm{~kg} / \mathrm{ha}$ than in kleingrass from the control plots. No differences in grass stands were attributed to formulation of tebuthiuron re-applied in 1977 .

The conversion of marginal or unmanaged native pastures to productive pastures depends on the successful establishment of high-quality forage species. Development of new herbicides may offer improved means of accomplishing this conversion by controlling competitive vegetation during the establishment period. The first objective of this study was to evaluate the effects of preplanting applications of glyphosate [N-(phosphono methyl) glycine] and tebuthiuron $\{\mathrm{N}-5$ (1, 1-dimethylethyl)-1,3,4-thiadiazol-2-yl]- $N N^{\prime}$-dimethylurea $\}$ on the establishment of Coastal Bermudagrass (Cynodon dactylon (L.) Pers.) and 'Selection 75' kleingrass (Panicum coloratum L.).

Following establishment of high-quality forage species, it is desirable to maintain the pasture at a high level of productivity. This is best accomplished by controlled grazing, fertilization, and weed control. The second objective of this study was to evaluate the effectiveness of tebuthiuron in three formulations for control of broadleaf weeds in established Coastal Bermudagrass and kleingrass pastures, and to determine productivity and grass quality in the kleingrass pasture after treatment.

\section{Materials and Methods}

The research was conducted in Leon County, in the Texas claypan region near Leona, Texas. Two sites were selected, one for establishment of a Bermudagrass pasture, the other for a kleingrass pasture.

Author is plant physiologist, U.S. Department of Agriculture. Science and Education Administration, Agricultural Research, College Station, Texas 77843

The research is a cooperative investigation of the Agric. Res., Sci. and Educ. Admin. U.S. Dep. Agr., and the Texas Agricultural Experiment Station, Department of Range Science, Texas A\&M Univ., College Station 77843

The author wishes to thank Mr. F.L. Thompson, Leona, Tex., for the unlimited use of the Spring Creek Ranch, for providing fences, and for land preparation.

Manuscript received January 16, 1978.
The Bermudagrass site was a 0.5 -ha clearing located on a deep sand adjacent to a flowing creek. The soil was of the Patilo series, classified as a grossaremic paleustalf, loamy, siliceous, thermic. The kleingrass site was a 1.2-ha clearing with a $2 \%$ slope. The soil on this site was similar to the Patilo, but had a much thinner surface layer than on the Bermudagrass site. The sites were about $0.4 \mathrm{~km}$ apart. Ten plots, 4.5 by $100 \mathrm{~m}$, were planted with Coastal Bermudagrass and 10 plots, 4.5 by $150 \mathrm{~m}$, were seeded with kleingrass. Both sites were fenced to prevent livestock grazing. Rainfall during the study was measured with a rain gauge at the Bermudagrass site.

\section{Preplanting Treatments}

Duplicate plots at each site were sprayed with tebuthiuron $(80 \%$ a.i. wettable powder) at 1.1 or $2.2 \mathrm{~kg} / \mathrm{ha}$ on January 21,1976 , or with glyphosate (isopropylamine salt formulation) at 1.1 or $2.2 \mathrm{~kg} / \mathrm{ha}$ on March 22, 1976. Two plots at each site were not treated and served as controls. Sprays were applied with a 4.5-m tractor-mounted boom calibrated to deliver 187 liters/ha. During the first week of May 1976, both sites were repeatedly disced until a suitable seedbed had been prepared. Discing was done only in the direction of the plots to minimize movement of the herbicides across plot boundaries. On May 20, 1976, Coastal Bermudagrass sprigs were hand broadcast at a rate of $440 \mathrm{~kg} / \mathrm{ha}$ and covered by discing. On the same day, $2.2 \mathrm{~kg}$ (viable seed)/ha of 'Selection 75 ' kleingrass were drilled 0.6 to $1.2 \mathrm{~cm}$ deep. The stand density of both grasses was visually evaluated on October $14,1976$.

In March 1977, eight plots, 9.1 by $45 \mathrm{~m}$, were superimposed across the 1976 preplanting treatment plots at both sites. On March 9, 1977, duplicate plots at each site were treated with tebuthiuron at $1.1 \mathrm{~kg} / \mathrm{ha}$ as an aqueous spray in 187 liters/ha or as extruded pellets, $1.6 \mathrm{~mm}$ or $3.2 \mathrm{~mm}$ in diameter. The extruded pellet formulations were $20 \%$ a.i. and were applied with a self-propelled broadcast distributor. Two plots at each site remained untreated. Both sites were fertilized with 13-13-13 at $448 \mathrm{~kg} / \mathrm{ha}$ on May 14, 1977.

\section{Evaluation}

On March 8, 1977, (before the 1977 subplot treatments were applied), the kleingrass stand was evaluated by estimating the percent cover of established plants in a $0.6-\mathrm{m}$ length of five alternate rows in each subplot. The starting point in each subplot was randomly selected by a blind toss of a range pole. All remaining evaluations were made on the basis of the $4.5-$ by $9.1-\mathrm{m}$ subplots created when the 1977 treatments were superimposed across the 1976 treatments.

On the 22nd and 23rd of June, 1977, kleingrass subplots were clipped and sampled for yield and quality evaluation. Three 56- by $91-\mathrm{cm}$ swaths were cut 5 to $8 \mathrm{~cm}$ above ground level in each subplot with an electric hedge clipper. The vegetation from each swath was separated into broadleaf weeds and kleingrass. Each fraction was weighed and two subsamples were weighed, dried at $60^{\circ} \mathrm{C}$, and reweighed for moisture determination.

On July 5, 1977, the botanical composition of Bermudagrass subplots was evaluated by estimation of foliar cover. Cover of Bermudagrass of broadleaf weeds, and of less desirable grasses, was visually estimated in ten $0.5-\mathrm{m}$ square areas in each subplot. The 
category of "less desirable" grasses included dallisgrass, carpetgrass (Axonopus affinis Chase.), crabgrass (Digitaria sp.), threeawns (Aristida sp.), and field sandbur (Cenchrus incertus M.A. Curtis). Broadleat weeds were primarily croton, with some common ragweed (Ambrosia artemisiifolia L.), coneflower (Rudbeckia sp.), and curly dock (Rumex crispus L.). Sedges (Carex sp.) and rushes (Juncus sp.) also occurred. The ten areas were delineated by a $0.5-\mathrm{m}$ square steel frame that was positioned uniformly in each subplot. Cover within each frame was estimated independently by two evaluators.

\section{Protein Analysis}

Subsamples of kleingrass taken for moisture determination from the control subplots and subplots treated with tebuthiuron in 1976 and 1977 were used for the protein determinations. A total of three 10-g samples of kleingrass was separated from two combined samples taken from each subplot. The dry grass was ground to pass a 20 -mesh screen in a Wiley mill. Total organic nitrogen was determined for duplicate $0.5-\mathrm{g}$ aliquots of each grass sample by the micro Kjeldahl method (AOAC 1960). Crude protein was calculated as $6.25 \times$ total organic nitrogen.

\section{Statistical Analysis}

All data were subjected to analysis of variance. Significant means $(p=0.05)$ were separated by the use of Duncan's multiple range test (Steel and Torrie 1960).

\section{Results and Discussion}

\section{Preplanting Treatments}

In October 1976, about $20 \%$ of the Coastal Bermudagrass had survived and was established in the control and glyphosatetreated plots. No Coastal Bermudagrass survived in the tebuthiuron-treated plots. This poor establishment was attributed in

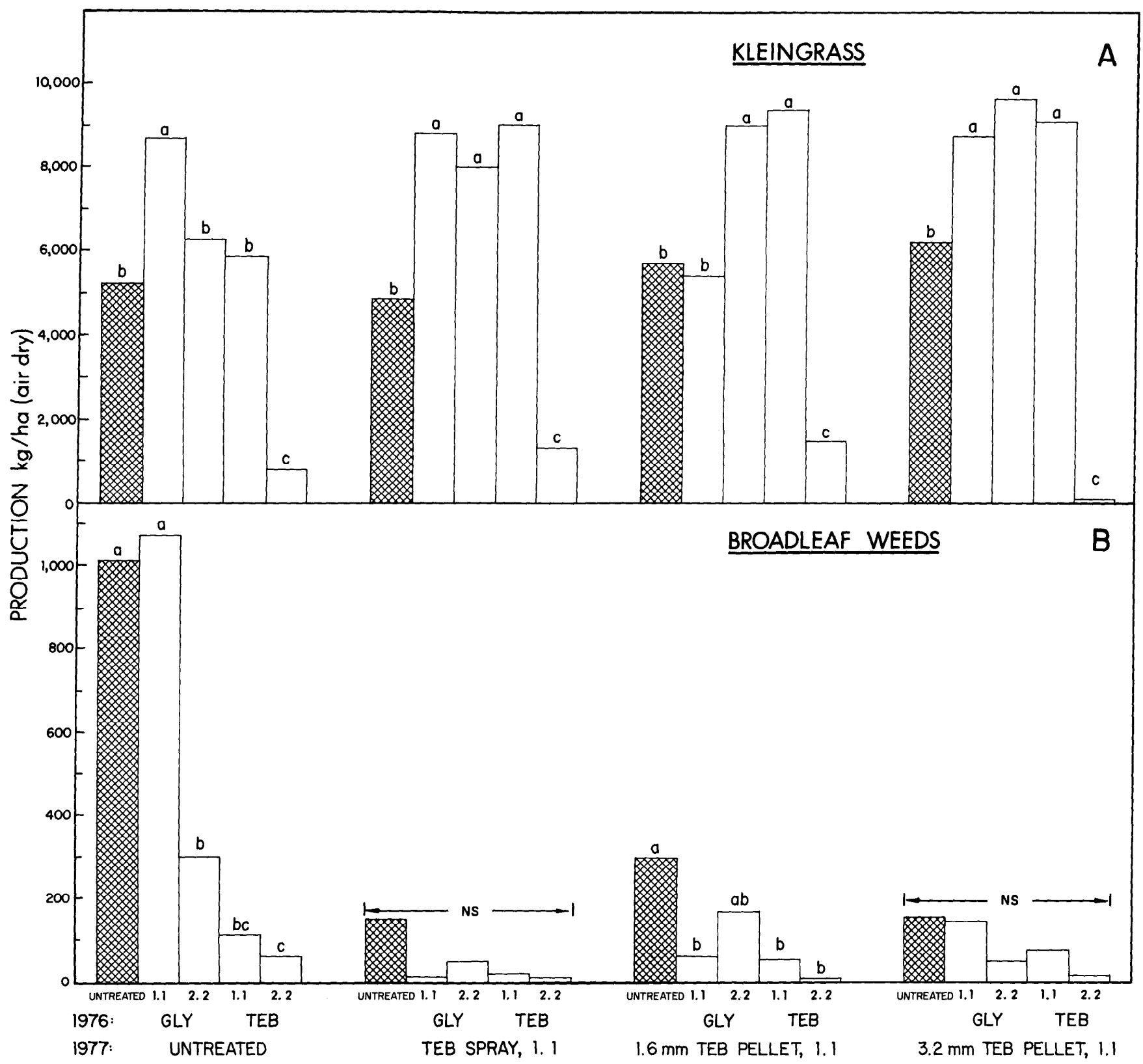

Fig. 1. Production of kleingrass (A) and broadleaf weeds $(B)$ with and without preplanting treatment in 1976 with glyphosate (GLY) or tebuthiuron (TEB) at $1 . I$ or $2.2 \mathrm{~kg} / \mathrm{ha}$ in 1976 and treatment with tebuthiuron at $1.1 \mathrm{~kg} / \mathrm{ha}$ in one of three formulations in 1977. Each bar represents the average of six 56- by 91 -cm harvest areas equally distributed between two subplots. Within any set of five bars, the same letter above the bars indicates that they are not significantly different at the $5 \%$ level. $N S=$ no significant differences. 
part to late planting and a dry summer. Weed cover appeared to be greater in the glyphosate-treated plots than the tebuthiurontreated plots. Common Bermudagrass cover was highest in the tebuthiuron-treated plots.

Tebuthiuron at $1.1 \mathrm{~kg} / \mathrm{ha}$ suppressed weed cover and permitted a kleingrass cover of $71 \%$. The higher rate of tebuthiuron $(2.2 \mathrm{~kg} / \mathrm{ha})$ prevented establishment of kleingrass, but not of invading common Bermudagrass and dallisgrass (Paspalum dilatatum Poir.). Kleingrass cover was 56 and $61 \%$ for plots treated with glyphosate at 1.1 and $2.2 \mathrm{~kg} / \mathrm{ha}$, respectively. Average cover in the control plots was $60 \%$. The glyphosate plots supported a moderate infestation of broadleaf weeds, primarily woolly croton (Croton capitatus Michx.).

Kleingrass production in plots that received preplanting treatments of glyphosate at $2.2 \mathrm{~kg} / \mathrm{ha}$ or tebuthiuron at $1.1 \mathrm{~kg} / \mathrm{ha}$ in 1976 (no 1977 treatment) was equivalent to that of the control (Fig. 1A). Kleingrass production was increased by glyphosate at $1.1 \mathrm{~kg} / \mathrm{ha}$ and was severely reduced by tebuthiuron at 2.2 $\mathrm{kg} / \mathrm{ha}$. Broadleaf weed control was good with both tebuthiuron treatments and with glyphosate at the high rate; glyphosate at the low rate was ineffective (Fig. 1B).

\section{Treatments}

Regardless of the 1977 herbicide applications, kleingrass production in all subplots treated with tebuthiuron at $2.2 \mathrm{~kg} / \mathrm{ha}$ in 1976 (preplanting) was less than that found in plots that had not received this treatment (Fig. 1A). For subplots treated with tebuthiuron at $1.1 \mathrm{~kg} / \mathrm{ha}$ in all three formulations applied in 1977 , production of kleingrass was significantly greater within those given preplanting treatments of glyphosate at 1.1 and 2.2 $\mathrm{kg} / \mathrm{ha}$ and tebuthiuron at $1.1 \mathrm{~kg} / \mathrm{ha}$ than in those left untreated in 1976 , with one exception. The exception was production from subplots treated with glyphosate at $1.1 \mathrm{~kg} / \mathrm{ha}$ before planting in 1976, and then treated with 1.6-mm tebuthiuron pellets in 1977. Production in these subplots was equivalent to that in the control subplots (Fig. 1A).

The 1977 tebuthiuron treatmens controlled broadleaf weeds satisfactorily on all subplots. Control was, however, slightly better on subplots that had also received preplanting treatments with either herbicide in 1976 (Fig. 1B). The increases in kleingrass production can be partially attributed to the removal of the competitive effects of broadleaf weeds. Comparisons among the graphs that represent kleingrass production and broadleaf weed control on subplots not treated in 1976 indicated that there were no differences in weed control among the three formulations of tebuthiuron applied at $1.1 \mathrm{~kg} / \mathrm{ha}$ in 1977 (Fig. 1).

The successful establishment of kleingrass and the satisfactory weed control in subplots that received the preplanting treatment with tebuthiuron at $1.1 \mathrm{~kg} / \mathrm{ha}$ might be attributed to the residual properties of this herbicide. Earlier work (Baur 1978) showed that tebuthiuron at $1.1 \mathrm{~kg} / \mathrm{ha}$ controlled annual weeds for 261 days with $68 \mathrm{~cm}$ of rainfall and allowed the subsequent establishment of annual ryegrass [Lolium perenne L. (including $L$. multiflorum Lam.)]. The conditions in the current study were 118 days and $45 \mathrm{~cm}$ rainfall between herbicide treatment and seeding. A second factor that could have influenced kleingrass production was the apparent tolerance of this species to tebuthiuron applied in the dormant season (Baur et al. 1977).

The effectiveness of glyphosate as a preplanting treatment is shown by the increased production of kleingrass in most of the treated subplots compared with control subplots (Fig. 1A). These increases probably resulted from the initial reduction in weed seedlings in 1976 before kleingrass seeding. The lack of a residual effect of glyphosate (Sprankle et al. 1975) precludes prolonged weed control during the establishment of the kleingrass seedlings.

For all 1977 treatments, except the 3.2-mm tebuthiuron pellets, levels of crude protein were significantly higher in kleingrass foliage from subplots given preplanting treatment with tebuthiuron at $1.1 \mathrm{~kg} / \mathrm{ha}$ than in plants from untreated subplots or subplots given preplanting treatment with tebuthiuron at $2.2 \mathrm{~kg} / \mathrm{ha}$ (Fig. 2). The higher production (Fig. 1A) and higher crude protein content (Fig. 2) for kleingrass from

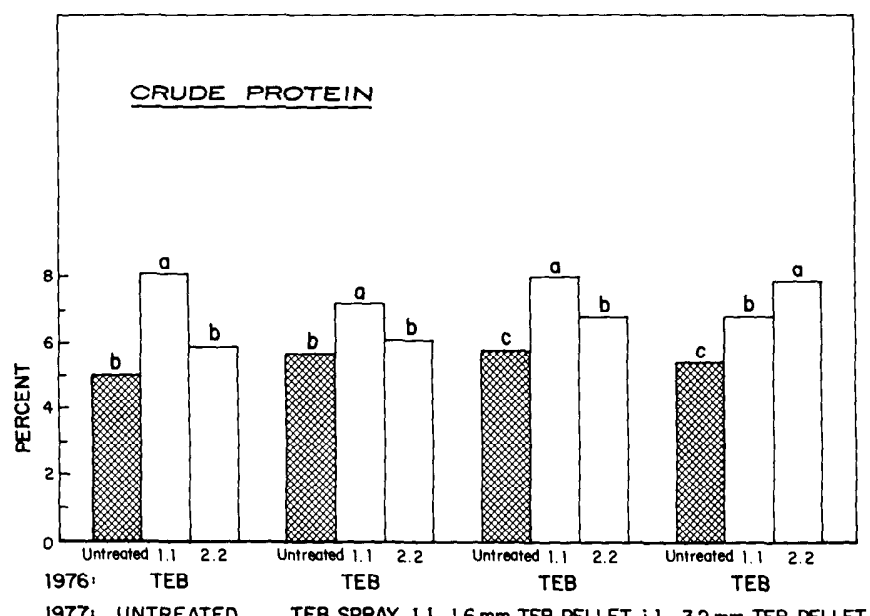

1977: UNTREATED

TEB SPRAY, $1.1 \quad 1.6 \mathrm{~mm}$ TEB PELLET, $i .1 \quad 3.2 \mathrm{~mm}$ TEB PELLET, 1.1

Fig. 2. Crude protein content of kleingrass with and without preplanting treatment with tebuthiuron (TEB) at 1.1 or $2.2 \mathrm{~kg} / \mathrm{ha}$ in 1976 and treatment with tebuthiuron at $1.1 \mathrm{~kg} / \mathrm{ha}$ in one of three formulations in 1977. Each bar represents the average of 12 determinations equally distributed between two subplots. Within any set of three bars, the same letter above the bars indicates that they are not significantly different at the 5\% level.

subplots given tebuthiuron at $1.1 \mathrm{~kg} / \mathrm{ha}$ as a preplanting treatment, compared with kleingrass from the untreated subplots, demonstrated the effect of reduced weed competition.

The highest crude protein level noted was $8.2 \%$. One explanation of the low protein levels is that no effort was made to separate leaves from stems. Levels of $13 \%$ and $5.5 \%$ were reported for kleingrass leaf and stem fractions, respectively (Polk et al. 1976).

Preplanting application of glyphosate at 1.1 or $2.2 \mathrm{~kg} / \mathrm{ha} \mathrm{had}$ little or no effect on Bermudagrass cover, regardless of the application of tebuthiuron the following season (Fig. 3A). Preplanting treatment with tebuthiuron at both rates, with no treatment in 1977, significantly increased Bermudagrass cover over that of the untreated control subplots. In subplots given a preplanting treatment with tebuthiuron and retreated in 1977, Bermudagrass cover was equivalent to that in subplots that were not given any preplanting treatment, and was sometimes significantly greater than that in subplots given a preplanting treatment with glyphosate. This finding suggests that a dormant-season application of tebuthiuron to established Bermudagrass might be beneficial during the next growing season. The estimates of broadleaf weed cover (Fig. 3B) support this conclusion. Subplots treated only in 1976 had weed cover estimated to be three to four times that found in subplots treated in both 1976 and 1977.

The reduction in Bermudagrass cover in subplots given glyphosate in 1976 (preplanting) was due partially to subsequent broadleaf weed competition, which was decreased by the 


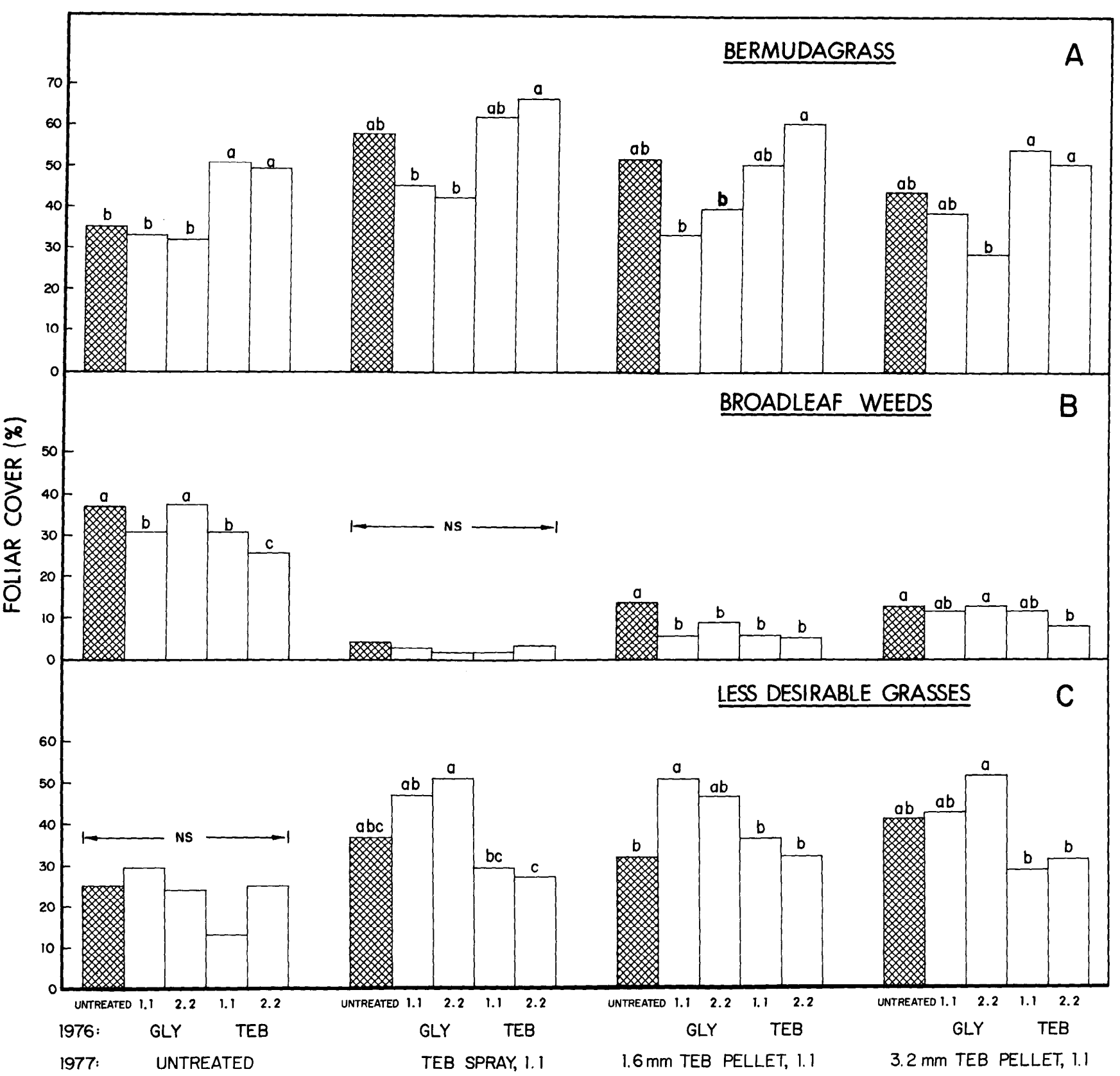

Fig. 3. Foliar cover $(\%)$ of Bermudagrass $(A)$, broadleaf weeds $(B)$ and less desirable grasses $(C)$ with and without preplanting treatment with glyphosate (GL $Y$ ) or tebuthiuron (TEB) at 1.1 or $2.2 \mathrm{~kg} / \mathrm{ha}$ in 1976 and treatment with tebuthiuron at $1.1 \mathrm{~kg} / \mathrm{ha}$ in 1977 . Each bar represents the average of two independent visual estimates of twenty $0.5-\mathrm{m}^{2}$ quadrats equally distributed between two subplots. Within any set of five bars, the same letter above the bars indicates that they are not significantly different at the $5 \%$ level. $N S=$ no significant differences.

preplanting application of tebuthiuron. The reduced Bermudagrass cover in these subplots apparently allowed establishment of less desirable grasses, whereas subplots that received tebuthiuron as a preplanting treatment (1976) had significantly lower covers of less desirable grasses (Fig. 3C).

Subplots treated only in 1976 (preplanting) had the lowest cover of less desirable grasses and the highest cover of broadleaf weeds (Fig. 3B, C). Broadleaf weed control from application of tebuthiuron at $1.1 \mathrm{~kg} / \mathrm{ha}$ in 1977 resulted in increased cover of Bermudagrass in the subplots given preplanting treatment with tebuthiuron and the less desirable grasses in the subplots given preplanting treatment with glyphosate (Fig. 3A, B, C).

Differences in Bermudagrass cover attributable to the formulation of tebuthiuron that was applied in 1977 were slight. The spray treatment gave slightly better control of broadleaf weeds than did the pellets.

\section{Literature Cited}

Association of Official Agricultural Chemists. 1960. Official methods of analysis (9th ed.). Ass. Offic. Agr. Chem., Washington, D.C. 832 p.

Baur, J.R. 1978. Effects of picloram and tebuthiuron on establishment of ryegrass winter pasture. J. Range Manage. 31:450-455.

Baur, J.R., R.W. Bovey, and E.C. Holt. 1977. Effect of herbicides on production and protein levels in pasture grasses. Agron. J. 69:846-851.

Polk, D.B.,Jr., C.J. Scifres, and J.L. Mutz. 1976. Establishment, production, and protein content of four grasses in South Texas. J. Range Manage. 29:240-243.

Sprankle, Paul, W.F. Meggitt, and D. Penner. 1975. Rapid inactivation of glyphosate in the soil. Weed Sci. 23:224-228.

Steel, R.G.D., and J.H. Torrie. 1960. Principles and Procedures of Statistics. McGraw-Hill, New York. 481 p. 